\title{
Global View of Biofuel Butanol and Economics of Its Production by Fermentation from Sweet Sorghum Bagasse, Food Waste, and Yellow Top Presscake: Application of Novel Technologies
}

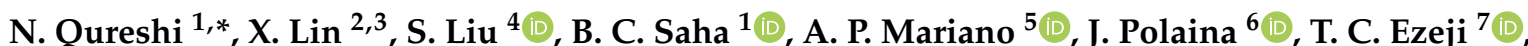
A. Friedl ${ }^{8}$ (D) I. S. Maddox ${ }^{9}$, K. T. Klasson ${ }^{10}$, B. S. Dien ${ }^{1}$ and V. Singh ${ }^{11}$ (D)

1 Bioenergy Research Unit, National Center for Agricultural Utilization Research (NCAUR), Agricultural Research Service (ARS), United States Department of Agriculture (USDA), 1815 N. University Street, Peoria, IL 61604, USA; Badal.saha@usda.gov (B.C.S.); Bruce.dien@usda.gov (B.S.D.)

2 School of Chemical Engineering and Light Industry, Guangdong University of Technology, No. 100 Waihuan Xi Road, Panyu District, Guangzhou 510006, China; linxiaoqing@gdut.edu.cn

3 Guangzhou Key Laboratory of Clean Transportation Energy Chemistry, Guangdong University of Technology, Guangzhou 510006, China

4 Renewable Products Technology, NCAUR, ARS, USDA, 1815 N. Univ. Street, Peoria, IL 61604, USA; Siqing.liu@usda.gov

5 School of Chemical Engineering, UNICAMP, Av Albert Einstein 500, Campinas, Sao Paulo 13083-852, Brazil; adpm@unicamp.br

6 Institute of Agricultural Chemistry and Food Technology-CSIC, 46980 Paterna, Valencia, Spain; jpolaina@iata.csic.es

7 Department of Animal Sciences, Ohio State Agricultural Research and Development Center (OARDC), The Ohio State University, 1680 Madison Avenue, Wooster, OH 44691, USA; ezeji.1@osu.edu

8 Institute of Chemical, Environmental, and Biological Engineering, TU-Wien (Vienna University of Technology), Getreidemarkt 9, A-1060 Vienna, Austria; anton.friedl@tuwien.ac.at

9 College of Sciences, Massey University, Auckland, New Zealand; iannoemi@xtra.co.nz

10 Southern Regional Research Center, ARS, USDA, New Orleans, LA 70124, USA; Thomas.Klasson@usda.gov

11 Integrated Bioprocessing Research Laboratory, University of Illinois, 1300 W Pennsylvania Ave, Urbana, IL 61801, USA; vsingh@illinois.edu

* Correspondence: Nasib.Qureshi@usda.gov

Received: 7 May 2020; Accepted: 31 May 2020; Published: 3 June 2020

\begin{abstract}
Worldwide, there are various feedstocks such as straws, corn stover, sugarcane bagasse, sweet sorghum bagasse (SSB), grasses, leaves, whey permeate, household organic waste, and food waste (FW) that can be converted to valuable biofuels such as butanol. For the present studies, an economic analysis was performed to compare butanol production from three feedstocks (SSB; FW; and yellow top presscake, YTP or YT) using a standard process and an advanced integrated process design. The total plant capacity was set at 170,000-171,000 metric tons of total acetone butanol ethanol (ABE) per year (99,300 tons of just butanol per year). Butanol production from SSB typically requires pretreatment, separate hydrolysis, fermentation, and product recovery (SHFR). An advanced process was developed in which the last three steps were combined into a single unit operation for simultaneous saccharification, fermentation, and recovery (SSFR). For the SHFR and SSFR plants, the total capital investments were estimated as $\$ 213.72 \times 10^{6}$ and $\$ 198.16 \times 10^{6}$, respectively. It was further estimated that the minimum butanol selling price (using SSB as a feedstock) for the two processes were $\$ 1.14 / \mathrm{kg}$ and $\$ 1.05 / \mathrm{kg}$. Therefore, SSFR lowered the production cost markedly compared to that of the base case. Butanol made using FW had an estimated minimum selling price of only $\$ 0.42 / \mathrm{kg}$. This low selling price is because the FW to butanol process does not require pretreatment, hydrolysis, and cellulolytic enzymes. For this plant, the total capital investment was projected to be $\$ 107.26 \times 10^{6}$. The butanol selling price using YTP as a feedstock was at $\$ 0.73 / \mathrm{kg}$
\end{abstract}


and $\$ 0.79 / \mathrm{kg}$ with total capital investments for SSFR and SHFR of $\$ 122.58 \times 10^{6}$ and $\$ 132.21 \times 10^{6}$, respectively. In the Results and Discussion section, the availability of different feedstocks in various countries such as Brazil, the European Union, New Zealand, Denmark, and the United States are discussed. Additionally, the use of various microbial strains and product recovery technologies are also discussed.

Keywords: butanol fermentation; feedstocks; capital investments; acetone; butanol selling price

\section{Introduction}

Due to fluctuating gasoline prices, climate change, and other detrimental environmental impacts from burning fossil fuels, developing butanol production using sustainable biomass feedstocks has attracted worldwide interest [1]. Bio-butanol (termed butanol hereafter) is an important C4 platform chemical that is biologically most often produced through the well-known acetone-butanol-ethanol (ABE) fermentation using solventogenic clostridial microorganisms [2-4]. Butanol is preferred as a sustainable additive or complete biofuel compared to bioethanol because of its high energy density, low flammability, hydrophobicity, no or low corrosiveness, and good miscibility with gasoline [4,5]. However, ABE fermentation has severe process constraints associated with its toxicity to microorganisms such as low final butanol concentration, slow butanol productivity, and energy inefficient product recovery, all of which have impaired the development of the butanol fermentation industry [5-7].

In the past 40 years, two solutions have been researched to address solvent toxicity [8-12]. The first is the development of superior microbial strains through molecular and metabolic engineering. Several Clostridia strains have been developed with increased butanol tolerance of strains and enhanced butanol ratio in the ABE solvent $[2,4,13]$; however, gains in solvent yields of the new strains are limited [14]. Presently, the maximum butanol concentration reported for a batch fermentation (without simultaneous product recovery) is only $20.9 \mathrm{~g} / \mathrm{L}$ for C. beijerinckii BA101, which was generated using nitrosoguanidine (NTG) mutagenesis [15]. As the boiling point of butanol $\left(118^{\circ} \mathrm{C}\right)$ is higher than water $\left(100{ }^{\circ} \mathrm{C}\right)$, solvent recovery from such a dilute fermentation broth by using traditional distillation is too energy-intensive and costly, and consumes too much water to be commercially feasible [5]. The other strategy is bioprocess optimization including the use of concentrated sugar solutions, high productivity reactor systems, simultaneous fermentation, and product recovery from the bioreactors, and production of butanol from less costly agricultural residues, food, municipal, and domestic organic wastes. Several in situ product removal (ISPR) techniques such as adsorption [16], liquid-liquid extraction [17], gas stripping [18,19], pervaporation [20], perstraction [21], and reverse osmosis [22] have been investigated for simultaneous butanol fermentation and recovery to maintain the concentration of butanol in the bioreactor below the threshold of toxicity, which dramatically enhances ABE productivity and sugar utilization in batch, fed-batch, and continuous reactors. Apart from the above improvement in productivity and sugar utilization, butanol produced from economically available agricultural residues including wheat straw [23], sugarcane bagasse [24], barley straw [25], corn stover [26,27], sweet sorghum bagasse [28], yellow top presscake [29], switchgrass [30], and numerous other biomasses is a very promising approach, which not only converts waste into superior biofuel, but also reduces environmental pollution.

In previous studies, we investigated the use of SSB, food waste, and YTP to produce bio-butanol [12,29,31]. However, it is important to consider additional factors such as the costs of enzymes, plant size, and consumption of steam and cooling water, all of which affect the cost of producing butanol from the SSB, FW, and YTP. Hence, one objective of this study was to model the processes and to compare butanol production costs for SSB, FW, and YTP using Clostridium beijerinckii P260. 


\section{Process Description}

\subsection{Biomass Pretreatment, Hydrolysis, Fermentation, and Recovery}

The cost of butanol production from SSB by fermentation was calculated for two processes. The first process was separate hydrolysis, fermentation, and recovery (SHFR) and the second process was simultaneous saccharification, fermentation, and recovery (SSFR). Prior to hydrolysis or saccharification, the SSB would be milled to approximately $0.8-1.0 \mathrm{~mm}$ sized particles followed by pretreatment using liquid hot water $\left(190^{\circ} \mathrm{C}\right)$ for less than $1 \mathrm{~min}$ before cooling. Upon cooling to $45^{\circ} \mathrm{C}$, the suspension was hydrolyzed using enzymes. In the SHFR process, pretreatment and hydrolysis were performed in separate tanks and fermentation and recovery were combined in one reactor. Butanol was recovered from the recovery tank by vacuum. A schematic diagram of this process with its four separate unit operations is shown in Figure 1A.
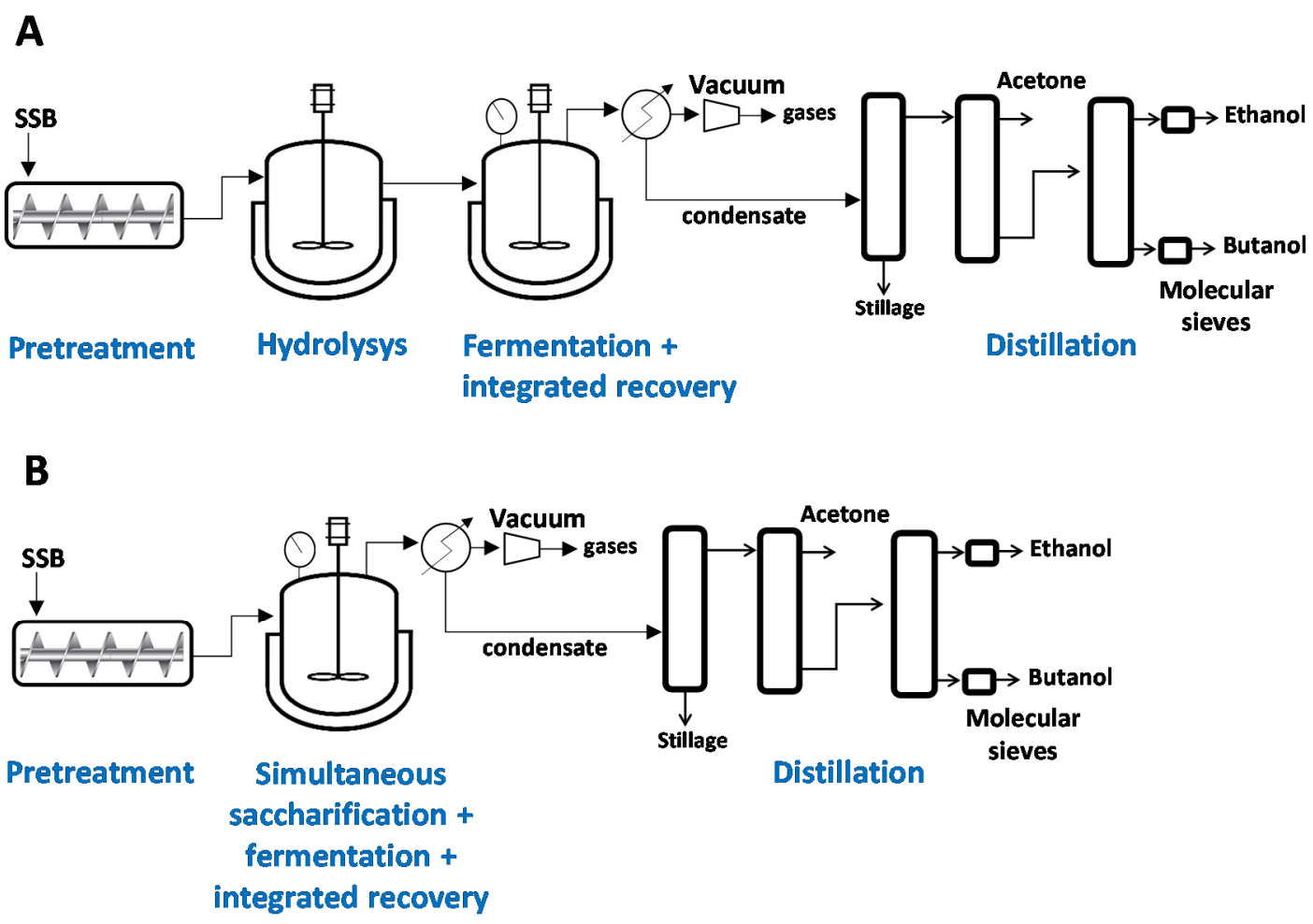

Figure 1. A schematic diagram of butanol production from sweet sorghum bagasse (SSB). (A) Diagram of pretreatment, separate hydrolysis, fermentation, and recovery (SHFR). (B) Combined process: Simultaneous saccharification, fermentation, and recovery (SSFR). Schematic diagram of the process of butanol production from YTP is the same as for SSB.

In the SSFR process, pretreatment was performed in a similar fashion as above. However, saccharification, fermentation, and recovery were combined using a single reactor, as shown in Figure 1B. Enzymes were added 12-15 h prior to inoculating the fermentation. When the butanol concentration reached 3-4 g/L, simultaneous recovery was initiated. Combined fermentation and butanol recovery continued until all the sugars available in SSB were utilized. In both processes, solvents (acetone butanol ethanol; after vacuum recovery) were separated using distillation. Butanol forms an azeotrope with water (approximately 750-800 g/L butanol; butanol density $810 \mathrm{~g} / \mathrm{L}$ ), which can be broken by using a molecular sieve to adsorb the last of the water. 


\subsection{Butanol Production from Food Waste (FW) and Yellow Top Presscake (YTP)}

It was assumed that an equivalent amount (equivalent to SSB) of FW would be used to produce butanol. Fermentation of FW would not require any nutrient supplements or pretreatment and hydrolysis reactors. It will also not require starch hydrolytic enzymes because the strain used degrades starch [32]. A process schematic for the processing of FW to butanol is presented in Figure 2.

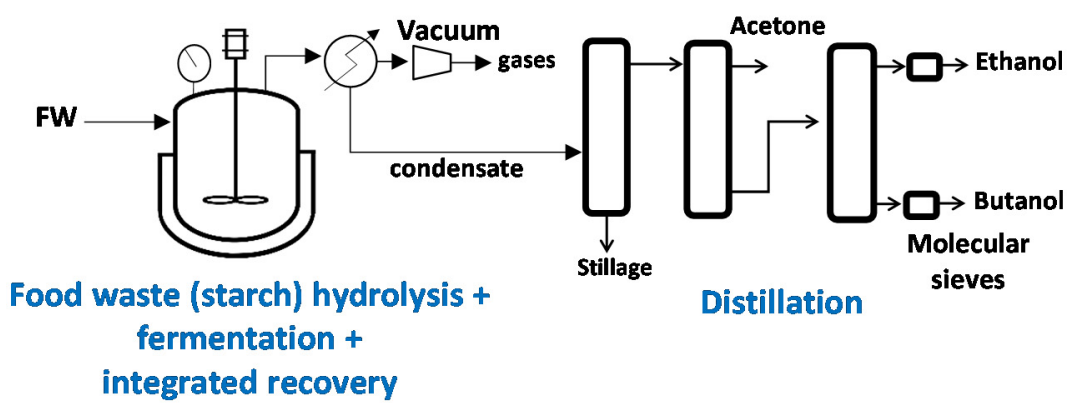

Figure 2. A schematic diagram of butanol production from food waste (FW).

YTP does require pretreatment at $160-190^{\circ} \mathrm{C}$ prior to hydrolysis as was the case with SSB. However, YTP would require only half the enzyme loading as SSB. Additionally, YTP hydrolysis, fermentation, and recovery would be combined and performed in a single tank. A schematic diagram for butanol production from YTP is the same as for that for SSB, as shown in Figure 1.

\subsection{Plant Capacity, Acetone-Butanol-Ethanol (ABE)/Butanol Yield, and Location}

The plant capacity was set at approximately 170,000-171,000 tons/year of total ABE of which the acetone, butanol, and ethanol production rates were 58,561,99,300, and 13,406 tons/year, respectively. This is the standard size plant for the production of biofuel/s in large countries such as the United States, Brazil, and the European Union. The plant was situated in the midwestern region of the United States where agricultural residues are abundant. In the case of whey permeate, wheat straw, or sugarcane bagasse, the plant locations were considered in the regions where these feedstocks are conveniently available. The plant was operated 350 days/year. The SSB cost was set at \$50/dry ton (personal communication; Eastern Regional Research Center, Wyndmoor, PA, USA). However, the sensitivity of the butanol minimum selling price to feedstock cost was determined by varying the latter. It was assumed that corn steep liquor (CSL) was required for cell growth and fermentation when using SSB and YTP. ABE yield based on SSB, FW, and YTP was taken as $0.28 \mathrm{~g} / \mathrm{g}$. It was assumed that the process water would be recycled. Credit was also taken for the fermentation off-gases $\left(\mathrm{CO}_{2}\right.$ and $\left.\mathrm{H}_{2}\right)$, lignin, and animal feed (derived from thermally deactivated cells). The process was modeled as a continuous fermentation. Process design, simulation, and costing were performed using a commercial-grade techno-economic software package (SuperPro Designer, version 10.07.2000). Process simulation included the estimation of capital and operational costs. A spreadsheet (Excel, Microsoft) was used to calculate the effect of varying the prices of SSB and enzymes on the cost of producing butanol.

\section{Results and Discussion}

\subsection{Butanol Production from Sweet Sorghum Bagasse (SSB)}

For the SHFR plant, the direct fixed capital, working capital, and startup costs were estimated to be $\$ 165.26 \times 10^{6}, \$ 40.2 \times 10^{6}$, and $\$ 8.26 \times 10^{6}$, respectively, thus bringing the total investment cost to $\$ 213.72 \times 10^{6}$. For this process, the rate of SSB biomass fed would be $609.80 \times 10^{6} \mathrm{~kg}$ of SSB biomass per year. Hydrolysis would use $53.66 \times 10^{6} \mathrm{~kg}$ of each of three hydrolytic enzymes (cellulase, $\beta$-glucosidase, and xylanase) (Table 1). In the two processes (SHFR \& SSFR), $76.58 \times 10^{6}$ and $72.73 \times 10^{6} \mathrm{kWh}$ of electricity would be used, respectively (Table 1 ). Compared to the SHFR 
process, a fixed capital of $\$ 153.22 \times 10^{6}$ would be required for the SSFR process (Table 2). This table compares investments, utilities, SSB, operating costs, credits, taxes, depreciation, and butanol selling price. As a result of combining the three unit operations (hydrolysis, fermentation, and recovery), the selling price of butanol obtained from the SSFR process is projected to be $\$ 1.05 / \mathrm{kg}$, as opposed to $\$ 1.14 / \mathrm{kg}$ for the SHFR process. In the base-case SSB-to-butanol production process, the cost of SSB of $\$ 50 /$ ton was considered. In actuality, this cost will vary and the effect of feedstock price changes on the butanol minimum selling price is shown in Figure 3. In our previous studies on the conversion of wheat straw to butanol, wheat straw was priced at \$24/ton [33]. The price of SSB is more than double that of wheat straw. Should this price decrease to $\$ 20 /$ ton, the butanol price would decrease to $\$ 0.95 / \mathrm{kg}$ for the SHFR process and $\$ 0.88 / \mathrm{kg}$ for the SSFR process. In the unlikely event that the price of SSB increases to $\$ 100 /$ ton, the butanol selling price would increase to $\$ 1.43$ and $\$ 1.36$ for the SHFR and SSFR processes, respectively.

Table 1. Amount of raw materials (SSB and enzymes; per year) and utilities for production of butanol in the SHFR and SSFR processes (per year).

\begin{tabular}{crr}
\hline & SHFR Process & \multicolumn{1}{c}{ SSFR Process } \\
\hline Raw Material & & \\
SSB [kg] & $609,772,800$ & $609,772,800$ \\
Cellulase [kg] & $53,659,200$ & $53,659,200$ \\
$\beta$-glucosidase [kg] & $53,659,200$ & $53,659,200$ \\
Xylanase [kg] & $53,659,200$ & $53,659,200$ \\
Utilities & & \\
Electricity [kWh] & $76,575,993$ & $72,729,020$ \\
Steam [MT] & 653,538 & 653,538 \\
High pressure steam [MT] & 107,674 & 107,674 \\
Cooling water [kg] & $648,604,949$ & $648,604,949$ \\
\hline
\end{tabular}

Table 2. Cost comparison of butanol production from SSB employing separate hydrolysis, fermentation, recovery (SHFR), and simultaneous saccharification, fermentation, and recovery (SSFR) processes.

\begin{tabular}{crr}
\hline & SHFR Process [\$] & SSFR Process [\$] \\
\hline Fixed capital & $165,256,000$ & $153,224,000$ \\
Working capital & $40,201,827$ & $37,274,802$ \\
Startup cost & $8,262,800$ & $7,661,200$ \\
Total investment & $\mathbf{2 1 3 , 7 2 0 , 6 2 7}$ & $\mathbf{1 9 8 , 1 6 0 , 0 0 2}$ \\
Raw material (SSB) & $30,488,640$ & $30,488,640$ \\
Cellulase & $5,365,920$ & $5,365,920$ \\
Xylanase & $5,365,920$ & $5,365,920$ \\
B-glucosidase & $5,365,920$ & $5,365,920$ \\
Total raw material (a) & $\mathbf{4 6 , 5 8 6 , 4 0 0}$ & $\mathbf{4 6 , 5 8 6 , 4 0 0}$ \\
Utilities & & \\
Electricity & $7,657,599$ & $7,272,902$ \\
Steam & $7,842,456$ & $7,842,456$ \\
High-pressure steam & $2,153,480$ & $2,153,480$ \\
Cooling water & $32,430,247$ & $32,430,247$ \\
Total utilities (b) & $\mathbf{5 0 , 0 8 3 , 7 8 2}$ & $\mathbf{4 9 , 6 9 9 , 0 8 5}$ \\
Operating costs & & \\
Labor-dependent & $5,216,000$ & $5,216,000$ \\
Facility-dependent & $40,312,000$ & $37,421,000$ \\
Laboratory (QC/QA) & 782,000 & 782,000 \\
Total operating costs (c) & $\mathbf{4 6 , 3 1 0 , 0 0 0}$ & $\mathbf{4 3 , 4 1 9 , 0 0 0}$ \\
Revenues/credits & & $11,261,376$ \\
Ethyl alcohol & $11,261,376$ &
\end{tabular}


Table 2. Cont

\begin{tabular}{crr}
\hline & SHFR Process [\$] & SSFR Process [\$] \\
\hline Acetone & $29,280,930$ & $29,280,930$ \\
Animal feed & $15,159,967$ & $15,417,670$ \\
Hydrogen \& $\mathrm{CO}_{2}$ & $42,009,446$ & $42,350,956$ \\
Total revenue/credit (d) & $\mathbf{9 7 , 7 1 1 , 7 1 9}$ & $\mathbf{9 8 , 3 1 0 , 9 3 2}$ \\
Expenses - credit (a + b + c - d) (e) & $\mathbf{4 5 , 2 6 8 , 4 6 4}$ & $\mathbf{4 1 , 3 9 3 , 5 5 3}$ \\
Profit (12\% ret on invest.) & $25,646,475$ & $23,779,200$ \\
Taxes (40\% on profit) & $10,258,590$ & $9,511,680$ \\
Depreciation (8-15\%) & $32,058,094$ & $29,724,000$ \\
Interest on investment & $8,548,825$ & $7,926,400$ \\
Total (profit \& taxes) (f) & $\mathbf{6 7 , 9 6 3 , 1 5 9}$ & $\mathbf{6 3 , 0 1 4 , 8 8 1}$ \\
Butanol (99,303,372 kg/yr) (g) & & \\
Butanol selling price [(e + f)/g] (\$/kg) & $\mathbf{1 . 1 4}$ & $\mathbf{1 . 0 5}$ \\
\hline
\end{tabular}

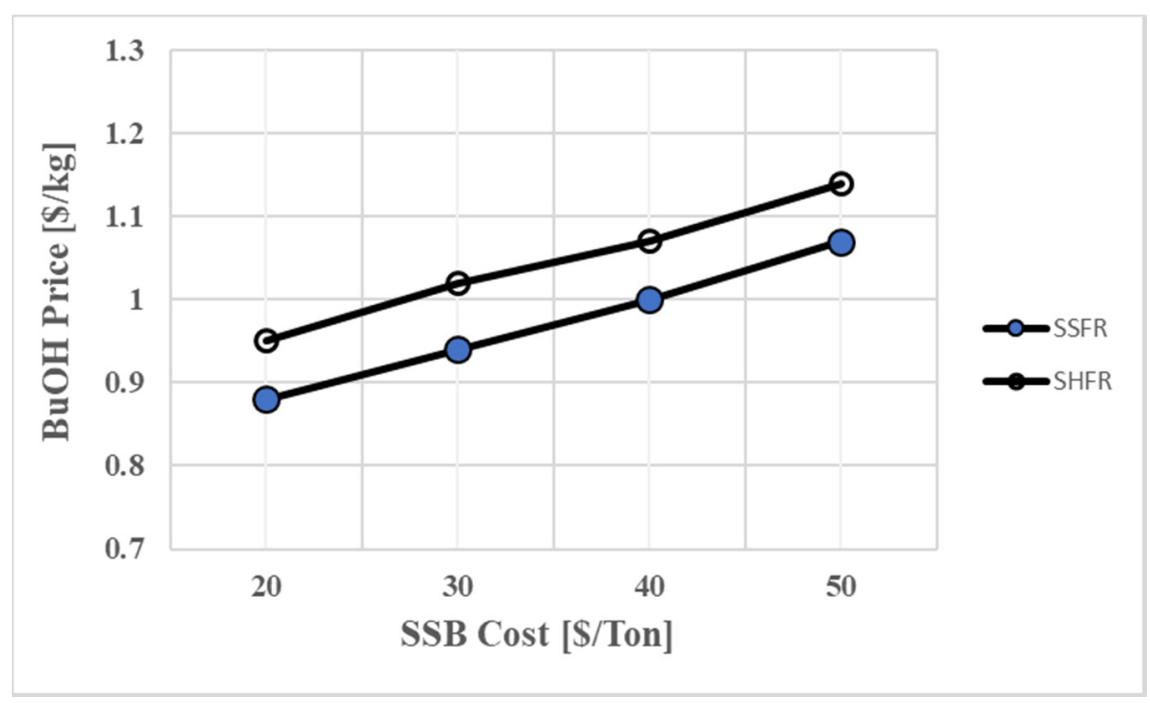

Figure 3. Effect of cost of SSB on the butanol selling price using SHFR and SSFR processes.

\subsection{Butanol Production from $F W$}

FW represents a valuable substrate for butanol production and its use for this biofuel production has been previously reported [12]. This substrate is rich in nutrients and does not require pretreatment or supplementation with hydrolytic enzymes. It is assumed that FW is a zero or negative cost (e.g., tipping fee) feedstock because using it for fermentation avoids disposing of it in landfills. Various assumptions taken for these cost studies are presented in Table 3. The total capital investment for this plant was estimated to be $\$ 107.26 \times 10^{6}$, which is significantly lower than the capital investment for the SSB butanol plant. As a result of the negligible cost of this feedstock $(\$ 0.00 / \mathrm{kg})$, a butanol selling price for this process was estimated to be $\$ 0.42 / \mathrm{kg}$. A negative cost of $\mathrm{FW}(-\$ 15 /$ ton) (due to tipping fees) would reduce the selling price of butanol to $\$ 0.33 / \mathrm{kg}$. A FW cost of $\$ 10 /$ ton would result in a butanol selling price of $\$ 0.49 / \mathrm{kg}$. It should be noted that FW to butanol plant would also be located in the midwestern region (like the SSB plant) of the United States, where FW could be transported from nearby cities such as Chicago, Indianapolis, and St. Louis. Should this plant be located close to a city, its capital investment would increase. Should this cost increase by $2-3$ fold, butanol selling price would be $\$ 0.90-1.35 / \mathrm{kg}$. However, it is unlikely that such a capital investment would increase by a factor of 2 . 
Table 3. Assumptions and butanol selling price for food waste (FW) to butanol process.

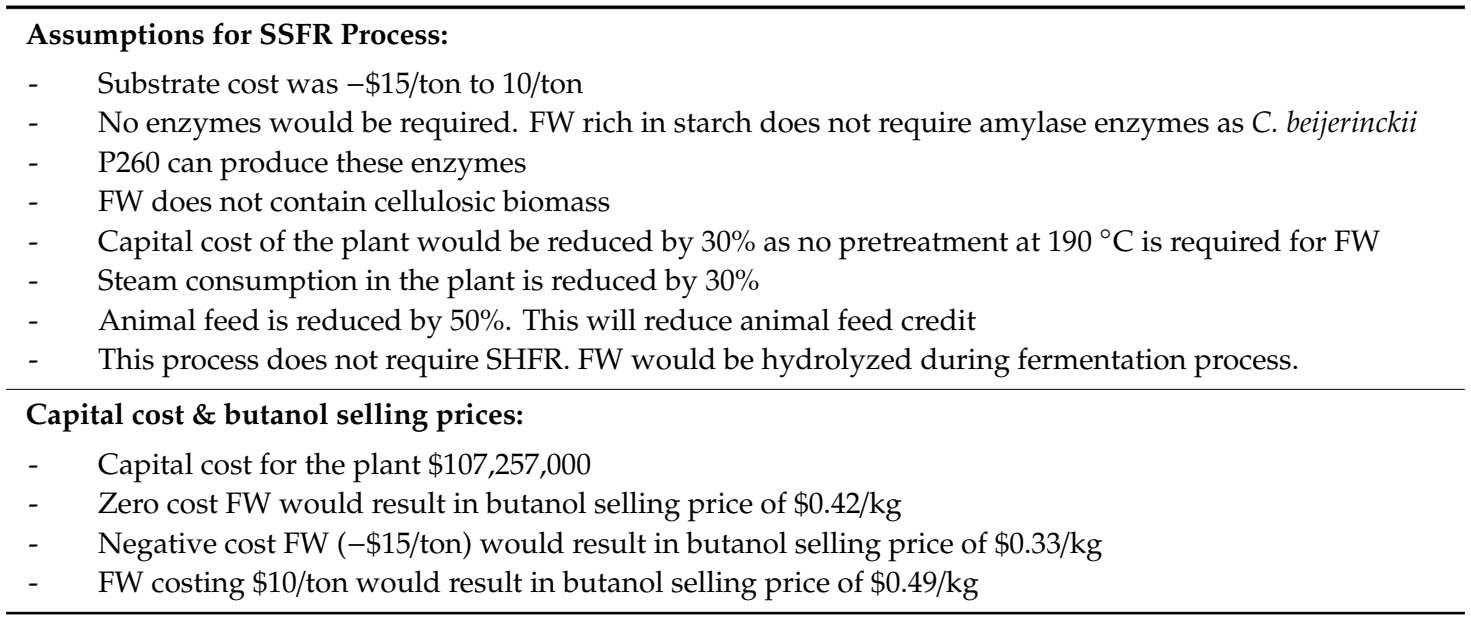

\subsection{Butanol Production from Yellow Top Presscake (YTP)}

For a butanol plant using YTP, the various assumptions are shown in Table 4. For the SSB plant, the feedstock price was considered to be \$50/ton, while for YTP it was assumed to be \$25/ton. This is because the YTP's disposal is proposed for landfills. Based on our experience on the YTP to butanol conversion [29], it was assumed that the requirement for enzymes would be reduced by $50 \%$. As compared to SSB's pretreatment $\left(190^{\circ} \mathrm{C}\right)$, the pretreatment of YTP would be carried out at $160-190^{\circ} \mathrm{C}$. YTP is rapidly liquified by cellulolytic enzymes compared to SSB. Based on these assumptions, it was projected that for a YTP to butanol conversion plant, the total capital investments would be $\$ 132.21 \times 10^{6}$ (SHFR) and $\$ 122.58 \times 10^{6}($ SSFR). The butanol selling price from a SHFR plant would be $\$ 0.79 / \mathrm{kg}$, while for a SSFR plant, it was projected to be $\$ 0.73 / \mathrm{kg}$.

Table 4. Assumptions and butanol selling price for yellow top presscake (YTP)-to-butanol conversion process.

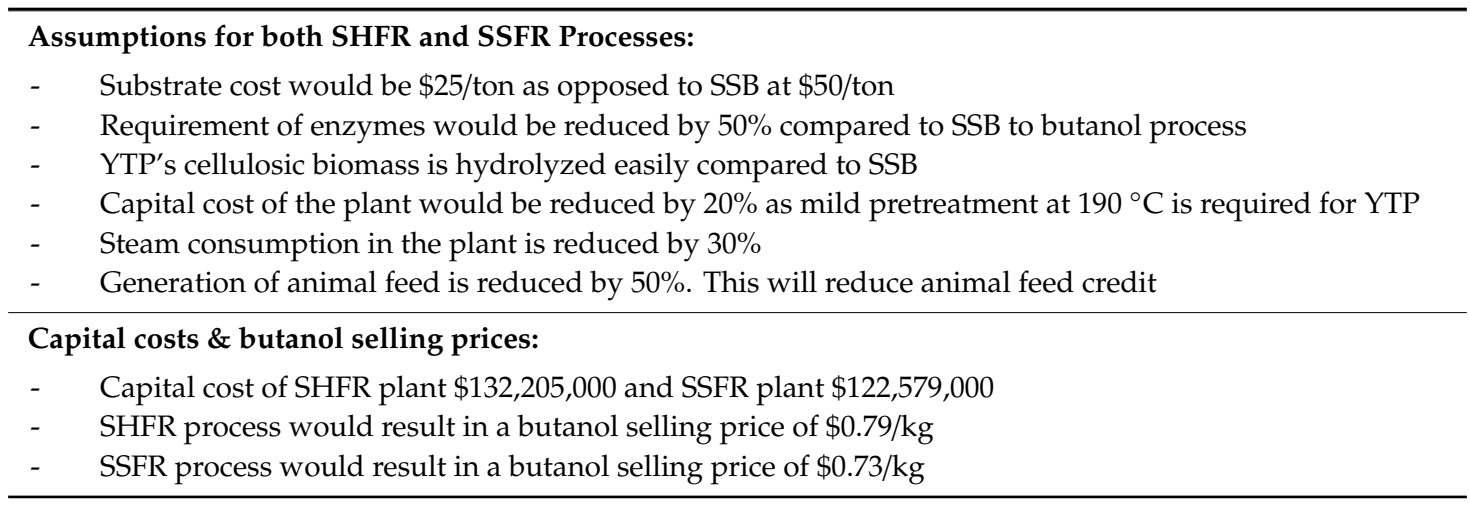

\subsection{Microbial Strains for Butanol Fermentation}

There are a number of butanol producing strains that can produce butanol from cellulosic hydrolyzates, corn (starch), whey permeate, FW, and YTP hydrolyzate. These strains include Clostridium acetobutylicum ATCC 824, C. saccharobutylicum P262, C. beijerinckii P260, and C. beijerinckii BA101. All these solventogenic Clostridium species and strains can utilize hexose and pentose sugars contained in SSB and YTP hydrolyzates. These strains can secrete amylolytic enzymes such as $\alpha$-amylase, $\beta$-amylase, and amyloglucosidase that hydrolyze starch or FW to simple sugars. The present studies are based on the results obtained from C. beijerinckii P260, an industrial strain used in industrial fermentation plant in South Africa. In our laboratory (United States Department of Agriculture, Peoria, 
IL, USA), this strain has been used to produce butanol from cellulosic hydrolyzates, FW, and YTP. Using this strain, ABE concentrations up to $29 \mathrm{~g} / \mathrm{L}$ were achieved in YTP hydrolyzates [34].

\subsection{Product Recovery Technologies}

As above-mentioned, there are several product recovery technologies that can be used to recover butanol from a fermentation broth [35-38]. For the current process, vacuum was chosen as the most suitable recovery technology from the fermentation broth of C. beijerinckii P260 [27]. This technique is simple, does not require any added chemicals, and the rate of recovery is many folds higher than other techniques.

\subsection{Other Feedstocks}

There are several other feedstocks that are commercial in nature and have low-value. These substrates include apple pomace, apple and pear drops, orchard waste, soy molasses, and starch-containing packing peanuts. Whey permeate (WP) is another feedstock that can be used for the production of butanol. This feedstock is a watery liquid that is obtained after the removal of cheese from milk. This contains approximately $45 \mathrm{~g} / \mathrm{L}$ lactose (milk sugar), which can be utilized by butanol producing strains [39]. For some butanol producing cultures including C. saccharobutylicum, this lactose concentration is ideal for butanol production as the culture cannot use $>45 \mathrm{~g} / \mathrm{L}$ lactose or sugar due to severe product inhibition. However, if $>45 \mathrm{~g} / \mathrm{L}$ lactose is required in the medium, it can be concentrated using reverse osmosis membranes [40]. Significant amounts of WP are produced in countries such as New Zealand, Denmark, and the state of Wisconsin, USA. However, it is considered that none of these countries will be able to supply enough WP to support 170,000 tons/year of ABE plant from this feedstock, but could meet the demands of smaller capacity plants (1840 tons ABE/year) [41].

In our previous studies, a cost estimation was performed for the production of butanol from wheat straw. For a plant capacity of 150,000 tons of butanol/year, the butanol production cost was projected to be $\$ 1.00 / \mathrm{kg}$ [33]. Both the U.S. $\left(3120 \times 10^{10} \mathrm{~kg} /\right.$ year $)$ and Europe $\left(20.55 \times 10^{10} \mathrm{~kg} /\right.$ year $)$ produce significant amounts of wheat straw and hence are suitable regions for butanol production plants. Another appropriate feedstock for butanol production is sugarcane bagasse. Brazil produces approximately $16.8 \times 10^{10} \mathrm{~kg}$ sugarcane bagasse each year. Cost of feedstock, pretreatment, and product recovery are some of the most cost influential factors for the production of commodity biofuels such as butanol. In the present study, a comparison of butanol selling prices from SSB, FW, and YTP was made and the results are shown in Figure 4.

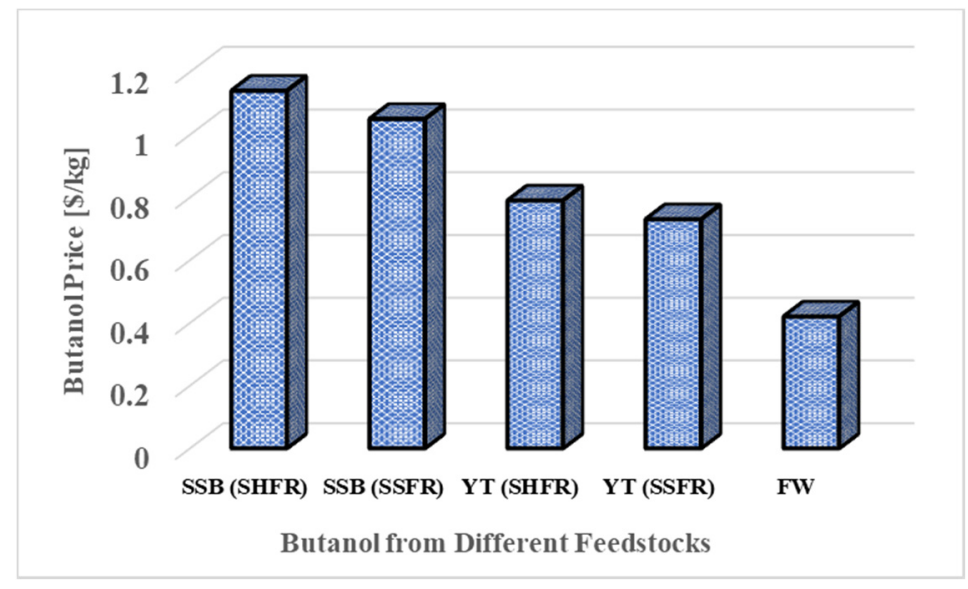

Figure 4. A comparison of butanol selling prices for the various substrates and processes. 


\section{Conclusions}

An economic analysis of the production of ABE, for a plant capacity of $\$ 170,000-171,000$ tons/year, from SSB suggests that butanol can be produced from this feedstock at a selling price of $\$ 1.14 / \mathrm{kg}$ using a SHFR process. The development of novel technologies such as SSFR, where three unit operations are combined into a single reactor, can lower the butanol selling price to $\$ 1.05 / \mathrm{kg}(92 \%$ of $\$ 1.14)$. These prices are based on purchasing SSB at $\$ 50 /$ ton. Feedstock costs were determined to be a major expense. When the price of SSB doubled (\$100/ton), the butanol selling prices for the SHFR and SSFR processes were calculated to be $\$ 1.43 / \mathrm{kg}$ and $\$ 1.36 / \mathrm{kg}$, respectively. The total capital investments for the two plants were estimated to be $\$ 213.72 \times 10^{6}$ and $\$ 198.16 \times 10^{6}$, respectively. When FW was considered to be a feedstock, the total capital investment (total investment) was estimated to be $\$ 107.26 \times 10^{6}$ and the butanol selling price was projected to be $\$ 0.42 / \mathrm{kg}$. FW, considered here as a negative value cost feedstock, would reduce this price further. These low butanol selling prices for FW are because it does not require pretreatment and hydrolysis enzymes. YTP is another potentially attractive feedstock that can be used for butanol production. Using YTP, the selling prices for the SHFR and SSFR processes were $\$ 0.79 / \mathrm{kg}(69.3 \%$ of $\$ 1.14)$ and $\$ 0.73 / \mathrm{kg}(64.0 \%)$, respectively, and the total capital investments for the two processes were estimated to be $\$ 132.21 \times 10^{6}$ and $\$ 122.58 \times 10^{6}$, respectively.

Author Contributions: Conceptualization, N.Q., V.S.; methodology, V.S.; software, B.S.D.; validation, B.S.D.; formal analysis, S.L., B.C.S., J.P., A.F., I.S.M., K.T.K.; investigation, N.Q.; writing-original draft preparation, N.Q., and X.L.; writing-review and editing, B.S.D., T.C.E., A.P.M.; and supervision, B.S.D. All authors have read and agreed to the published version of the manuscript.

Funding: This research received no external funding.

Acknowledgments: Xiaoqing Lin contributed to this manuscript while working as a visiting scientist at the Bioenergy Research Unit, NCAUR, ARS, USDA located in Peoria, IL, USA. Mention of trade names or commercial products in this publication is solely for the purpose of providing scientific information and does not imply recommendation or endorsement by the U.S. Department of Agriculture. USDA is an equal opportunity provider and employer.

Conflicts of Interest: The authors declare no conflicts of interest.

\section{References}

1. Dürre, P. Biobutanol: An attractive biofuel. Biotechnol. J. 2007, 2, 1525-1534. [CrossRef] [PubMed]

2. Kumar, M.; Gayen, K. Developments in biobutanol production: New insights. Appl. Energy 2011, 88, 1999-2012. [CrossRef]

3. Jones, D.T.; Woods, D.R. Acetone-butanol fermentation revisited. Microbiol. Rev. 1986, 50, 484-524. [CrossRef] [PubMed]

4. Lee, S.Y.; Park, J.H.; Jang, S.H.; Nielsen, L.K.; Kim, J.; Jung, K.S. Fermentative butanol production by Clostridia. Biotechnol. Bioeng. 2008, 101, 209-228. [CrossRef]

5. Lin, X.; Wu, J.; Fan, J.; Qian, W.; Zhou, X.; Qian, C.; Jin, X.; Wang, L.; Bai, J.; Ying, H. Adsorption of butanol from aqueous solution onto a new type of macroporous adsorption resin: Studies of adsorption isotherms and kinetics simulation. J. Chem. Technol. Biotechnol. 2012, 87, 924-931. [CrossRef]

6. Lin, X.; Wu, J.; Jin, X.; Fan, J.; Li, R.; Wen, Q.; Qian, W.; Liu, D.; Chen, X.; Chen, Y. Selective separation of biobutanol from acetone-butanol-ethanol fermentation broth by means of sorption methodology based on a novel macroporous resin. Biotechnol. Prog. 2012, 28, 962-972. [CrossRef] [PubMed]

7. Jin, Q.; Qureshi, N.; Wang, H.; Huang, H. Acetone-butanol-ethanol (ABE) fermentation of soluble and hydrolyzed sugars in apple pomace by Clostridium beijerinckii P260. Fuel 2019, 244, 536-544. [CrossRef]

8. Liu, D.; Chen, Y.; Ding, F.; Guo, T.; Xie, J.; Zhuang, W.; Niu, H.; Shi, X.; Zhu, C.; Ying, H. Simultaneous production of butanol and acetoin by metabolically engineered Clostridium acetobutylicum. Metab. Eng. 2015, 27, 107-114. [CrossRef]

9. Ezeji, T.; Qureshi, N.; Blaschek, H. Acetone butanol ethanol (ABE) production from concentrated substrate: Reduction in substrate inhibition by fed-batch technique and product inhibition by gas stripping. Appl. Microbiol. Biotechnol. 2004, 63, 653-658. [CrossRef] 
10. Lin, X.; Xiong, L.; Qi, G.; Shi, S.; Huang, C.; Chen, X.; Chen, X. Using butanol fermentation wastewater for biobutanol production after removal of inhibitory compounds by micro/mesoporous hyper-cross-linked polymeric adsorbent. ACS Sustain. Chem. Eng. 2015, 3, 702-709. [CrossRef]

11. Mariano, A.P.; Qureshi, N.; Filho, R.M.; Ezeji, T.C. Bioproduction of butanol in bioreactors: New insights from simultaneous in situ butanol recovery to eliminate product toxicity. Biotechnol. Bioeng. 2011, 108, 1757-1765. [CrossRef] [PubMed]

12. Huang, H.; Singh, V.; Qureshi, N. Butanol production from food waste: A novel process for producing sustainable energy and reducing environmental pollution. Biotechnol. Biofuels 2015, 8, 147. [CrossRef] [PubMed]

13. Ezeji, T.C.; Qureshi, N.; Blaschek, H.P. Butanol fermentation research: Upstream and downstream manipulations. Chem. Record. 2004, 4, 305-314. [CrossRef] [PubMed]

14. Lin, Y.-L.; Blaschek, H.P. Butanol production by a butanol-tolerant strain of Clostridium acetobutylicum in extruded corn broth. Appl. Environ. Microbiol. 1983, 45, 966-973. [CrossRef]

15. Chen, C.-K.; Blaschek, H.P. Acetate enhances solvent production and prevents degeneration in Clostridium beijerinckii BA101. Appl. Microbiol. Biotechnol. 1999, 52, 170-173. [CrossRef]

16. Liu, D.; Chen, Y.; Ding, F.-Y.; Zhao, T.; Wu, J.-L.; Guo, T.; Ren, H.-F.; Li, B.-B.; Niu, H.-Q.; Cao, Z.; et al. Biobutanol production in a Clostridium acetobutylicum biofilm reactor integrated with simultaneous product recovery by adsorption. Biotechnol. Biofuels 2014, 7, 5. [CrossRef]

17. Grobben, N.G.; Eggink, G.; Cuperus, F.P.; Huizing, H.J. Production of acetone, butanol and ethanol (ABE) from potato wastes: Fermentation with integrated membrane extraction. Appl. Microbiol. Biotechnol. 1993, 39, 494-498. [CrossRef]

18. Qureshi, N.; Blaschek, H.P. Recovery of butanol from fermentation broth by gas stripping. Renew. Energy 2001, 22, 557-564. [CrossRef]

19. Xue, C.; Zhao, J.; Liu, F.; Lu, C.; Yang, S.-T.; Bai, F.-W. Two-stage in-situ gas stripping for enhanced butanol fermentation and energy-saving product recovery. Bioresour. Technol. 2013, 135, 396-402. [CrossRef]

20. Liu, G.; Wei, W.; Jin, W. Pervaporation membranes for biobutanol production. ACS Sustain. Chem. Eng. 2014, 2, 546-560. [CrossRef]

21. Qureshi, N.; Maddox, I.S. Reduction in butanol inhibition by perstraction: Utilization of concentrated lactose/whey permeate by Clostridium acetobutylicum to enhance butanol fermentation economics. IChemE Food Bioprod. Proc. 2005, 83, 43-52. [CrossRef]

22. Garcia, A., III; Iannotti, E.L.; Fischer, J.L. Butanol fermentation liquor production and separation by reverse osmosis. Biotechnol. Bioeng. 1986, 28, 785-791. [CrossRef] [PubMed]

23. Qureshi, N.; Saha, B.C.; Cotta, M.A. Butanol production from wheat straw hydrolysate using Clostridium beijerinckii. Bioproc. Biosys. Eng. 2007, 30, 419-427. [CrossRef] [PubMed]

24. Pang, Z.-W.; Lu, W.; Zhang, H.; Liang, Z.-W.; Liang, J.-J.; Du, L.-W.; Duan, C.-J.; Feng, J.-X. Butanol production employing fed-batch fermentation by Clostridium acetobutylicum GX01 using alkali-pretreated sugarcane bagasse hydrolysed by enzymes from Thermoascus aurantiacus QS 7-2-4. Bioresour. Technol. 2016, 212, 82-91. [CrossRef] [PubMed]

25. Qureshi, N.; Saha, B.C.; Dien, B.; Hector, R.E.; Cotta, M.A. Production of butanol (a biofuel) from agricultural residues: Part I-Use of barley straw hydrolysate. Biomass Bioenergy 2010, 34, 559-565. [CrossRef]

26. Xu, G.-C.; Ding, J.-C.; Han, R.-Z.; Dong, J.-J.; Ni, Y. Enhancing cellulose accessibility of corn stover by deep eutectic solvent pretreatment for butanol fermentation. Bioresour. Technol. 2016, 203, 364-369. [CrossRef] [PubMed]

27. Qureshi, N.; Singh, V.; Liu, S.; Ezeji, T.C.; Saha, B.C.; Cotta, M.A. Process integration for simultaneous saccharification, fermentation, and recovery (SSFR): Production of butanol from corn stover using Clostridium beijerinckii P260. Bioresour. Technol. 2014, 154, 222-228. [CrossRef]

28. Cai, D.; Chang, Z.; Gao, L.; Chen, C.; Niu, Y.; Qin, P.; Wang, Z.; Tan, T. Acetone-butanol-ethanol (ABE) fermentation integrated with simplified gas stripping using sweet sorghum bagasse as immobilized carrier. Chem. Eng. J. 2015, 277, 176-185. [CrossRef]

29. Qureshi, N.; Harry-O'kuru, R.; Liu, S.; Saha, B. Yellow top (Physaria fendleri) presscake: A novel substrate for butanol production and reduction in environmental pollution. Biotechnol. Prog. 2019, 35, e2767. [CrossRef] 
30. Ezeji, T.C.; Qureshi, N.; Blaschek, H.P. Production of acetone butanol (AB) from liquefied corn starch, a commercial substrate, using Clostridium beijerinckii coupled with product recovery by gas stripping. J. Ind. Microbiol. Biotechnol. 2007, 34, 771-777. [CrossRef]

31. Qureshi, N.; Saha, B.C.; Klasson, K.T.; Liu, S. Butanol production from sweet sorghum bagasse with high solids content: Part I—comparison of liquid hot water pretreatment with dilute sulfuric acid. Biotechnol. Prog. 2018, 34, 960-966. [CrossRef] [PubMed]

32. Gutierrez, N.A.; Maddox, I.S.; Schuster, K.C.; Swoboda, H.; Gapes, J.R. Strain comparison and medium preparation for the acetone-butanol-ethanol (ABE) fermentation process using a substrate of potato. Bioresour. Technol. 1998, 66, 263-265. [CrossRef]

33. Qureshi, N.; Saha, B.C.; Cotta, M.A.; Singh, V. An economic evaluation of biological conversion of wheat straw to butanol: A biofuel. Energy Conv. Manag. 2013, 65, 456-462. [CrossRef]

34. Qureshi, N.; Saha, B.; Liu, S.; Harry-O'kuru, R. Production of acetone-butanol-ethanol (ABE) from concentrated yellow top presscake using Clostridium beijerinckii P260. J. Chem. Technol. Biotechnol. 2020, 95, 614-620. [CrossRef]

35. Groot, W.J.; van der Lans, R.G.J.M.; Luyben, K.C.A. Technologies for butanol recovery integrated with fermentations. Proc. Biochem. 1992, 27, 61-75. [CrossRef]

36. Maddox, I.S. The acetone-butanol-ethanol fermentation: Recent progress in technology. Biotechnol. Genet. Eng. Rev. 1989, 7, 189-220. [CrossRef]

37. Qureshi, N. Solvent (Acetone-Butanol: AB) production. In Reference Module in Life Science; Roitberg, B., Ed.; Elsevier: Oxford, UK, 2017; pp. 1-20.

38. Friedl, A. Downstream process options to the ABE fermentation. FEMS Microbiol. Lett. 2016, 363, 1-5. [CrossRef]

39. Maddox, I.S.; Qureshi, N.; Gutierrez, N.A. Utilization of whey and process technology by Clostridia. In The Clostridia and Biotechnology; Woods, D.R., Ed.; Butterworth Heinemann: Boston, MA, USA, 1993; pp. 343-369.

40. Qureshi, N.; Manderson, G.J. Bioconversion of renewable resources into ethanol: An economic evaluation of selected hydrolysis, fermentation, and membrane technologies. Energy Sources 1995, 17, 241-265. [CrossRef]

41. Qureshi, N.; Maddox, I.S. Application of novel technology to the ABE fermentation process: An economic analysis. Appl. Biochem. Biotechnol. 1992, 34/35, 441-448. [CrossRef] 